\title{
Some Biological Activities of Ethanol Extract of Marrubium globosum
}

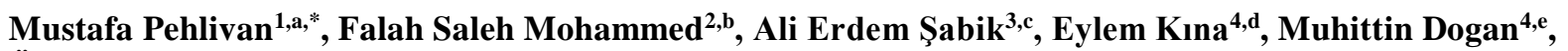 \\ Önder Yumrutaş ${ }^{5, f}$, Mustafa Sevindik ${ }^{6, g}$ \\ ${ }^{1}$ Department of Medical and Aromatic Plants, Nurdagi Vocational Higher School, Gaziantep University, 27310 Gaziantep, Turkey \\ ${ }^{2}$ Department of Biology, Faculty of Science, Zakho University, Duhok, Iraq \\ ${ }^{3}$ Department of Chemistry and Chemical Processing Technologies, Bahçe Vocational School, Osmaniye Korkut Ata University, 80010 Osmaniye, Turkey \\ ${ }^{4}$ Department of Biology, Faculty of Science and Literature, Gaziantep University, 27310 Gaziantep, Turkey \\ ${ }^{5}$ Department of Medical Biology, Faculty of Medicine, Adiyaman University, 02100 Adiyaman, Turkey \\ ${ }^{6}$ Department of Food Processing, Bahçe Vocational School, Osmaniye Korkut Ata University, 80010 Osmaniye, Turkey
}

*Corresponding author

\begin{tabular}{l|l} 
A R T I C L E I N F O & A B S T R A C T \\
\hline $\begin{array}{l}\text { Research Article } \\
\text { Received : } 17 / 04 / 2021 \\
\text { Accepted : } 27 / 05 / 2021\end{array}$ & $\begin{array}{l}\text { Plants have been used for centuries to treat various diseases. In this study, Marrubium globosum } \\
\text { Montbret and Aucher ex Benth. plant was used as a material. The extract of the plant was extracted } \\
\text { with the help of soxhlet device using ethanol, which is a good polar solvent, and Rel Assay kits } \\
\text { were used to determine the oxidant and antioxidant levels in the plant extract. Antifungal and } \\
\text { antibacterial activities of } M . \text { globosum were tested against standard bacteria and fungus strains by } \\
\text { agar dilution method. As a result of the analysis, TAS value of plant extract was determined as } \\
7.677 \pm 0.231, \text { TOS value as } 12.387 \pm 0.083 \text { and OSI value as } 0.162 \pm 0.004 . \text { In this context, it has been } \\
\text { observed that the plant has an important antioxidant potential. In addition, the plant extract was } \\
\text { found to be effective against test microorganisms at 50-200 } \mu \mathrm{g} / \mathrm{mL} \text { extract concentrations. As a } \\
\text { result, it has been determined that } M . \text { globosum can be a natural antioxidant and antimicrobial } \\
\text { source. }\end{array}$ \\
$\begin{array}{l}\text { Keywords: } \\
\text { Antimicrobial }\end{array}$
\end{tabular}

Antimicrobial

Antioxidant

Medicinal Plants

Marrubium globosum

Oxidant

\begin{abstract}
Plants have been used for centuries to treat various diseases. In this study, Marrubium globosum Montbret and Aucher ex Benth. plant was used as a material. The extract of the plant was extracted antibacterian strains by agar dilution method. As a result of the analysis, TAS value of plant extract was determined as $7.677 \pm 0.231$, TOS value as $12.387 \pm 0.083$ and OSI value as $0.162 \pm 0.004$. In this context, it has been observed that the plant has an important antioxidant potential. In addition, the plant extract was result, it has been determined that $M$. globosum can be a natural antioxidant and antimicrobial source.
\end{abstract}

mpehlivan27@hotmail.com erdemsabik@osmaniye.edu.tr doganm@gantep.edu.tr sevindik27@gmail.com

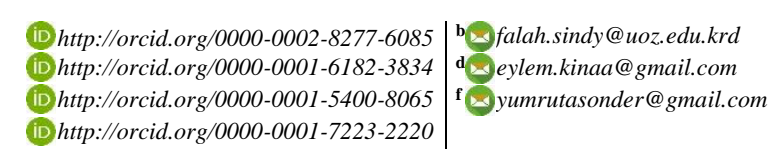

(iD) http://orcid.org/0000-0001-9083-1876 (iD http://orcid.org/0000-0003-4538-9737 (iD) http://orcid.org/0000-0001-9657-8306

\section{Introduction}

Breathing, which is an indispensable action for the continuation of life, actually brings some dangers with it. Although undoubtedly the element is essential for life, most of the biochemical reactions it participates in generate free radicals that contain oxygen as a by-product. These highly reactive chemical wholes can damage or even kill cells when they reach high levels (Marx, 1987; Loix et al., 2017). Free radicals have an important effect on tissue damage as well as cellular damage. Oxidative stress is an increase in oxidant level and/or a decrease in antioxidant level, especially in conditions that are pathological for the body, shifting the balance in oxidative metabolism to the oxidative direction (Sevindik, 2020). Oxidants often have a damaging effect on cells, mitochondria, nuclei and membranes. Free radicals that affect DNA in particular cause irreversible damage to the organism (Dadheech et al., 2008). The antioxidant system especially ensures that the effect of reactive oxygen species (ROS) formation is minimized and neutralized (Tunçel et al., 2015). In cases where the antioxidant system is insufficient, taking supplemental antioxidants plays an important role in reducing oxidative damage. In this context, it is very important to investigate the antioxidant effects of natural products (Tewari et al., 2021). Many materials obtained from natural ecosystems have been used by humans in the treatment of diseases. Plants in particular have been used 
by humans for different purposes such as the treatment of diseases, nutrition, shelter, defense and warming, and they are still being used. In recent years, many researchers have reported that different plant species have different biological activities such as antioxidant, antimicrobial, anticancer, antiproliferative, anti-inflammatory, DNA preservative, anti-aging, antidepressant, antiallergic, hypoglycemic (Hu et al., 2017; Ayoub et al., 2018; Khan et al., 2018; Lichota and Gwozdzinski, 2018; Miastkowska and Sikora, 2018; Ribeiro et al., 2018; Salehi et al., 2019; Guo et al., 2020; Salehi et al., 2020; Mohammed et al., 2021).

In this study, antioxidant and antimicrobial activities of M. globosum were determined. The genus Marrubium (Lamiaceae) includes about 40 species growing mainly throughout the Mediterranean and in the temperate regions of the Eurasian continent. Most of the species are annual or perennial rhizomatous plants, usually containing a separate indumentum of very complex hairs (Mabberley, 1997). It has been reported that $M$. globosum ssp. libanoticum is used in the treatment of inflammatory diseases, asthma, cough and other lung and urinary problems (Rigano et al., 2009). Flavonoids and phenylethanoids have also been reported as chemical constituents of Marrubium spp., but it is also well known that the genus contains a wide variety of diterpenoids (Hatam et al., 1995; Karioti et al., 2005).

\section{Materials and Methods}

M. globosum examples of Turkey (Gaziantep) were collected from. Plant identification was made using Flora of Turkey volume 7 (Davis, 1982; 173). The aerial parts of the samples were separated and dried in a shaded and ventilated environment. Then $30 \mathrm{~g}$ of the samples were weighed. It was then extracted at $500 \mathrm{C}$ with $200 \mathrm{~mL}$ of EtOH for about 6 hours (Gerhardt EV 14). The solvents of the extracts obtained were removed in a concentrator. (Heidolph Laborota 4000 Rotary Evaporator).

\section{Antimicrobial Activity Studies}

The extract concentrations of the plant's EtOH extract against bacteria and fungi were determined using the agar dilution method (CLSI, 2012; EUCAST, 2014; EUCAST, 2015). Different concentrations of the plant extract were adjusted with distilled water. Bacterial strains (Staphylococcus aureus ATCC 29213, S. aureus MRSA ATCC 43300, Enterococcus faecalis ATCC 29212, Escherichia coli ATCC 25922, Pseudomonas aeruginosa ATCC 27853 and Acinetobacter baumannii ATCC 19606) were cultured in Muller Hinton Broth medium and Amikacin, Ampicillin and Ciprofloxacin were used as reference drugs. Fungus strains (Candida albicans ATCC 10231, C. krusei ATCC 34135 and C. glabrata ATCC 90030) were cultured in RPMI 1640 Broth medium and Fluconazole and Amphotericin B were used as reference drugs (Bauer et al., 1966; Hindler et al., 1992; Matuschek et al., 2014).

\section{Antioxidant and Oxidant Tests}

The total antioxidant and oxidant levels of the plant extract were measured according to the protocol specified in the Rel Assay kits. The antioxidant status was determined using TAS kit, oxidant status was determined using TOS kit (Erel, 2004; Erel, 2005). Trolox was used as the calibrator in the antioxidant status test and hydrogen peroxide as the calibrator in the oxidant status test. The oxidative stress index (OSI: Arbitrary unit (AU)) was determined according to the formula below (Sevindik, 2019).

$$
\text { OSI }(\mathrm{AU})=\frac{\mathrm{TOS}, \mu \text { mol } \mathrm{H}_{2} \mathrm{O}_{2} \text { equiv. } / \mathrm{L}}{\text { TAS, mmol Trolox equiv./ } \mathrm{L} \times 10}
$$

\section{Results and Discussion}

\section{Antimicrobial Potential}

Plants have many biological activities thanks to the secondary metabolites they produce. In recent years, the number of microbial diseases has been increasing (Danish et al., 2020). Chemically synthesized antibiotics are used extensively in the fight against these diseases (Zazharskyi et al., 2019). However, due to the possible side effects of chemical antibiotics and resistant microorganisms, the trend towards natural products has increased (Mostafa et al., 2018). In this context, the use of plants with high biological activities is increasing. In our study, the potential of EtOH extract of $M$. globosum against bacteria and fungi was investigated. The findings obtained are shown in Table 1.

Antimicrobial potentials of different species belonging to the genus Marrubium have been reported in previous studies. From these studies, it has been reported that Marrubium peregrinum, acetone, ethyl acetate and methanol extracts are effective against Escherichia coli, Pseudomonas aeruginosa, Salmonella enterica, Proteus mirabilis, Enterococcus faecalis, Staphylococcus aureus, Sarcina lutea, Bacillus subtilis, Bacillus cereus and Bacillus pumilus in different concentrations (Radojević et al., 2013). Methanol extract of Marrubium globosum ssp. libanoticum has been reported to be effective against Staphylococcus epidermidis, S. aureus, Enterococcus faecalis, Bacillus subtilis, Proteus mirabilis, P. vulgaris, Pseudomonas aeruginosa, Salmonella typhi, Enterobacter aerogenes, E. cloacae, Klebsiella pneumoniae and Escherichia coli (Rigano et al., 2007). It has been reported that the essential oil of Marrubium astracanicum ssp. astracanicum is effective against Brevibacillus brevis, B. megaterium, $B$. subtilis, B. cereus, Staphylococcus aureus and Listeria monocytogenes (Kilic and Özdemir, 2017). In our study, it was determined that the EtOH extract of Marrubium globosum was effective against E. faecalis, E. coli, and $A$. baumannii at $50 \mu \mathrm{g} / \mathrm{mL}, P$. aeruginosa and $C$. glabrata at $100 \mu \mathrm{g} / \mathrm{mL}, S$. aureus, S. aureus MRSA, C. albicans and $C$. kruse $i$ at $100 \mu \mathrm{g} / \mathrm{mL}$. In this context, it has been determined that $M$. globosum has antimicrobial activity. As a result, it has been determined that it can be an antimicrobial natural source.

\section{Antioxidant Status}

Aerobic organisms reduce the effects of oxidant compounds with their antioxidant defense system, which includes enzymatic and non-enzymatic mechanisms. The use of supplemental antioxidants is very important in situations where endogenous antioxidants are insufficient (Korkmaz et al., 2018). Due to the effects of herbal antioxidants, interest in these natural materials is increasing. 
Table 1. Antimicrobial Activity of Marrubium globosum

\begin{tabular}{c|ccccccccc}
\hline Extract & A & B & C & D & E & F & G & H & J \\
\hline EtOH & 200 & 200 & 50 & 50 & 100 & 50 & 100 & 200 & 200 \\
\hline
\end{tabular}

*(A) S. aureus, (B) S. aureus MRSA, (C) E. faecalis, (D) E. coli, (E) P. aeruginosa, (F) A. baumannii, (G) C. glabrata, (H) C. albicans, (J) C. Krusei, *200, 100, $50 \mu \mathrm{g} / \mathrm{mL}$ extract concentrations

$\underline{\text { Table 2. TAS, TOS and OSI values of Marrubium globossum }}$

\begin{tabular}{c|ccc}
\hline Material & TAS & TOS & OSI \\
\hline M. globossum & $7.677 \pm 0.231$ & $12.387 \pm 0.083$ & $0.162 \pm 0.004$ \\
\hline \multicolumn{4}{l}{ Values are presented as mean \pm SD }
\end{tabular}

The use of herbal products as supplementary antioxidants as supplements to endogenous antioxidants may delay oxidative damage (Kim et al., 2017). In this study, antioxidant (TAS) and oxidant (TOS) levels of $M$. globosum were determined. The findings obtained are shown in Table 2.

TAS, TOS and OSI values of $M$. globosum were not previously reported, and were determined for the first time in this study. In studies on different plant species, TAS value of Allium calocephalum has been reported as 5.853 $\mathrm{mmol} / \mathrm{L}$, TOS value as $16.288 \mu \mathrm{mol} / \mathrm{L}$ and OSI value as 0.278 (Mohammed et al., 2019). The TAS value of Mentha longifolia subsp. longifolia has been reported as 3.628 $\mathrm{mmol} / \mathrm{L}$, TOS value as $4.046 \mu \mathrm{mol} / \mathrm{L}$ and OSI value as 0.112 (Sevindik et al., 2017). The TAS value of Rhus coriaria var. zebaria has been reported as $7.342 \mathrm{mmol} / \mathrm{L}$, TOS value as $5.170 \mu \mathrm{mol} / \mathrm{L}$ and OSI value as 0.071 (Mohammed et al., 2018). TAS value of Scorzonera papposa has been reported as $5.314 \mathrm{mmol} / \mathrm{L}$, TOS value as $24.199 \mu \mathrm{mol} / \mathrm{L}$ and OSI value as 0.473 (Mohammed et al., 2020a). The TAS value of Gundellia tournefortii has been reported as $6.831 \mathrm{mmol} / \mathrm{L}$, TOS value as $3.712 \mu \mathrm{mol} / \mathrm{L}$ and OSI value as 0.054 (Saraç et al., 2019). The TAS value of Ferulago platycarpa has been reported as $5.688 \mathrm{mmol} / \mathrm{L}$, TOS value as $15.552 \mu \mathrm{mol} / \mathrm{L}$ and OSI value as 0.273 (Mohammed et al., 2020b). The TAS value of Rumex crispus has been reported as $6.758 \mathrm{mmol} / \mathrm{L}$, TOS value as $5.802 \mu \mathrm{mol} / \mathrm{L}$ and OSI value as 0.086 (Daştan et al., 2019). When compared with these studies, the TAS value of $M$. globosum was determined to be higher than M. longifolia subsp. longifolia, A. calocephalum, G. tournefortii, $R$. coriaria var. zebaria, $R$. crispus, $S$. papposa and $F$. platycarpa. TAS value shows the whole of the antioxidant active compounds in the plant (Akgül et al., 2020). Plants with high TAS values are very important in terms of antioxidant compound. According to the data of the study we conducted in this context, it was seen that the TAS value of $M$. globosum was high, and as a result, it was determined that the plant could be an important natural antioxidant source.

The TOS value shows the whole of the oxidant compounds produced by the plant as a result of environmental and structural effects and metabolic activities (Akgül et al., 2020). In this context, the TOS value of $M$. globosum was determined higher than $R$. crispus, $R$. coriaria var. zebaria, G. tournefortii and M. longifolia subsp. longifolia, and lower than $F$. platycarpa, S. papposa and $A$. calocephalum. It is seen that the higher the TOS value, the more harmful the level of oxidant compounds in the plant. In this context, it is seen that the TOS value of $M$. globosum used in our study is at normal levels. In addition, the OSI value indicates the balance of the oxidant compounds in the plant's body and the antioxidant defense system. As the OSI value increases, it indicates that the antioxidant defense system is insufficient to suppress oxidant compounds (Akgül et al., 2020). In this context, it was seen that the OSI value of M. globosum was lower than $F$. platycarpa, S. papposa and A. calocephalum, and higher than $R$. coriaria var. zebaria, $R$. crispus, $G$. tournefortii and $M$. longifolia subsp. longifolia. As a result, it is seen that $M$. globosum is successful in suppressing oxidant compounds. In this context, it is thought that the plant can be used as a natural antioxidant agent.

\section{Conclusion}

In this study, the antioxidant, antibacterial and antifungal potential of $M$. globosum was determined. The study has shown that the plant has an important antioxidant potential. In this context, it is thought that it can be used as a natural antioxidant agent. In addition, it was determined that the plant has antimicrobial activity against standard bacteria and fungi. As a result, it is thought that $M$. globosum can be used as a natural pharmacological agent.

\section{References}

Akgul H, Korkmaz N, Dayangaç A, Sevindik M. 2020. Antioxidant Potential of Endemic Salvia absconditiflora. Turkish Journal of Agriculture-Food Science and Technology, 8(10): 2222-2224.

Ayoub IM, Korinek M, Hwang TL, Chen BH, Chang FR, ElShazly M, Singab ANB. 2018. Probing the antiallergic and anti-inflammatory activity of biflavonoids and dihydroflavonols from Dietes bicolor. Journal of natural products, 81(2): 243-253.

Bauer AW, Kirby WM, Sherris JC, Turck M. 1966. Antibiotic susceptibility testing by a standardized single disk method, Am J Clin Pathol, 45: 493-96.

CLSI, 2012. (The Clinical and Laboratory Standards Institute) Antimicrobial Susceptibility Testing of Anaerobic Bacteria; Approved Standard-Eighth Edition (M11-A8).

Dadheech G, Mishra S, Gautam S, Sharma P. 2008. Evaluation of antioxidant deficit in schizophrenia. Indian Journal of Psychiatry, 50(1): 16-20.

Danish P, Ali Q, Hafeez MM, Malik A. 2020. Antifungal and antibacterial activity of aloe vera plant extract. Biol Clin Sci Res J, 1-8

Daştan SD, Durukan H, Demirbaş A, Dönmez E. 2019. Bioactivity and Therapeutic Properties of Evelik (Rumex crispus), A Naturally Growing and Edible Plant in Sivas Province. Turkish Journal of Agriculture-Food Science and Technology, 7(sp2): $67-71$.

Erel O. 2004. A novel automated direct measurement method for total antioxidant capacity using a new generation, more stable ABTS radical cation. Clinical biochemistry, 37(4): 277-285.

Erel O. 2005. A new automated colorimetric method for measuring total oxidant status. Clinical biochemistry, 38(12): 1103-1111.

EUCAST, 2014. (European Committee on Antimicrobial Susceptibility Testing) Breakpoint tables Fungal isolate for interpretation of MICs. Version 7.0.

EUCAST, 2015. (European Committee on Antimicrobial Susceptibility Testing) Breakpoint tables for Bacteria interpretation of MICs and zone diameters, Version 5.0.

Guo Y, Shang H, Zhao J, Zhang H, Chen S.2020. Enzyme-assisted extraction of a cup plant (Silphium perfoliatum L.) polysaccharide and its antioxidant and hypoglycemic activities. Process Biochemistry, 92: 17-28. 
Hatam NA, Porzel A, Seifert K. 1995. Polyodonine, a prefuranic labdane diterpene from Marrubium polydon. Phytochemistry, 40(5): 1575-1576.

Hindler J, Hochstein L, Howell A. 1992. Preparation of routine media and reagents used in antimicrobial susceptibility testing. Part 1. McFarland standards, p. 5.19.1-5.19.6. In H D. Isenberg (ed) Clinical microbiology procedures handbook, vol. 1. American Society for Microbiology, Washington, D.C.

Hu QP, Cao XM, Hao DL, Zhang LL. 2017. Chemical composition, antioxidant, DNA damage protective, cytotoxic and antibacterial activities of Cyperus rotundus rhizomes essential oil against foodborne pathogens. Scientific reports, 7(1): 1-9.

Karioti A, Heilmann J, Skaltsa H. 2005. Labdane diterpenes from Marrubium velutinum and Marrubium cylleneum. Phytochemistry, 66(9): 1060-1066.

Khan H, Perviz S, Sureda A, Nabavi SM, Tejada S. 2018. Current standing of plant derived flavonoids as an antidepressant. Food and Chemical Toxicology, 119: 176-188.

Kiliç Ö, Özdemir FA. 2017. Composition and Antimicrobial Activities of Marrubium astracanicum Jacq. subsp. astracanicum Essential Oil. Journal of Essential Oil-Bearing Plants, 20(5): 1400-1406.

Kim YH, Khan AL, Waqas M, Lee IJ. 2017. Silicon regulates antioxidant activities of crop plants under abiotic-induced oxidative stress: a review. Frontiers in Plant Science, 8: 510.

Korkmaz AI, Akgul H, Sevindik M, Selamoglu Z. 2018. Study on determination of bioactive potentials of certain lichens. Acta Alimentaria, 47(1): 80-87.

Krupodorova T, Sevindik M. 2020. Antioxidant potential and some mineral contents of wild edible mushroom Ramaria stricta. AgroLife Sci J, 9: 186-191.

Lichota A, Gwozdzinski K. 2018. Anticancer activity of natural compounds from plant and marine environment. International journal of molecular sciences, 19(11): 3533.

Loix C, Huybrechts M, Vangronsveld J, Gielen M, Keunen E, Cuypers A. 2017. Reciprocal interactions between cadmiuminduced cell wall responses and oxidative stress in plants. Frontiers in Plant Science, 8: 1867.

Mabberley David J. 1997. The plant-book: a portable dictionary of the vascular plants. Cambridge university press.

Matuschek E, Brown DF, Kahlmeter G. 2017. Development of the EUCAST disk diffusion antimicrobial susceptibility testing method and its implementation in routine microbiology laboratories, Clin Microbiol Infect, 20: 255-266.

Miastkowska M, Sikora E. 2018. Anti-aging properties of plant stem cell extracts. Cosmetics, 5(4): 55.

Mohammed FS, Akgul H, Sevindik M, Khaled BMT. 2018. Phenolic content and biological activities of Rhus coriaria var. zebaria. Fresenius Environmental Bulletin, 27(8): 5694-5702.

Mohammed FS, Günal S, Pehlivan M, Doğan M, Sevindik M, Akgül H. 2020a. Phenolic Content, Antioxidant and Antimicrobial Potential of Endemic Ferulago platycarpa. Gazi University Journal of Science, 33(4): 670-677.

Mohammed FS, Günal S, Şabik AE, Akgül H, Sevindik M. 2020b. Antioxidant and Antimicrobial activity of Scorzonera papposa collected from Iraq and Turkey. Kahramanmaraş Sütçü İmam Üniversitesi Tarım ve Doğa Dergisi, 23(5): 1114-1118.

Mohammed FS, Karakaş M, Akgül H, Sevindik M. 2019. Medicinal properties of Allium calocephalum collected from Gara Mountain (Iraq). Fresen Environ Bull, 28(10): 7419-7426.

Mohammed FS, Pehlivan M, Sevindik E, Akgul H, Sevindik M, Bozgeyik I, Yumrutas O. 2021. Pharmacological properties of edible Asparagus acutifolius and Asparagus officinalis collected from North Iraq and Turkey (Hatay). Acta Alimentaria, 50(1): 136-143.
Mostafa AA, Al-Askar AA, Almaary KS, Dawoud TM, Sholkamy EN, Bakri MM. 2018. Antimicrobial activity of some plant extracts against bacterial strains causing food poisoning diseases. Saudi Journal of Biological Sciences, 25(2): 361-366.

Radojević I, Stanković M, Stefanović O, Čomić L, Topuzović M, Vasić S, Nikolić M. 2013. Exploring antimicrobial activity of horehound, Marrubium peregrinum L. extracts. Kragujevac J. Sci, 35: 99-106.

Ribeiro VP, Arruda C, Abd El-Salam M, Bastos JK. 2018. Brazilian medicinal plants with corroborated antiinflammatory activities: A review. Pharmaceutical biology, 56(1): 253-268.

Rigano D, Formisano C, Basile A, Lavitola A, Senatore F, Rosselli S, Bruno M. 2007. Antibacterial activity of flavonoids and phenylpropanoids from Marrubium globosum ssp. libanoticum. Phytotherapy Research: An International Journal Devoted to Pharmacological and Toxicological Evaluation of Natural Product Derivatives, 21(4): 395-397.

Rigano D, Formisano C, Basile A, Lavitola A, Senatore F, Rosselli S, Bruno M. 2007. Antibacterial activity of flavonoids and phenylpropanoids from Marrubium globosum ssp. libanoticum. Phytotherapy Research: An International Journal Devoted to Pharmacological and Toxicological Evaluation of Natural Product Derivatives, 21(4): 395-397.

Salehi B, Gültekin-Özgüven M, Kırkın C, Özçelik B, MoraisBraga MFB, Carneiro JNP, Bezerra CF, da Silva TG, Coutinho HDM, Amina B, Armstrong L, Selamoglu Z, Sevindik M, Yousaf Z, Sharifi-Rad J, Muddathir AM, Devkota HP, Martorell M, Jugran AK, Martins N, Cho WC. 2019. Anacardium plants: chemical, nutritional composition and biotechnological applications. Biomolecules, 9(9): 465.

Salehi B, Gültekin-Özgüven M, Kirkin C, Özçelik B, MoraisBraga MFB, Carneiro JNP, Bezerra CF, da Silva TG, Coutinho HDM, Amina B, Armstrong L, Selamoglu Z, Sevindik M, Yousaf Z, Sharifi-Rad J, Muddathir AM, Devkota HP, Martorell M, Jugran AK, Cho W, Martins N. 2020. Antioxidant, antimicrobial, and anticancer effects of anacardium plants: an ethnopharmacological perspective. Frontiers in Endocrinology, 11: 295.

Saraç H, Demirbaş A, Daştan SD, Ataş M, Çevik Ö, Eruygur N. 2019. Evaluation of Nutrients and Biological Activities of Kenger (Gundellia tournefortii L.) Seeds Cultivated in Sivas Province. Turkish Journal of Agriculture-Food Science and Technology, 7(sp2): 52-58.

Sevindik M. 2018. Pharmacological properties of Mentha species. J Tradit Med Clin Natur, 7(2): 259.

Sevindik M. 2019. The novel biological tests on various extracts of Cerioporus varius. Fresenius Environmental Bulletin, 28(5): 3713-3717.

Sevindik M. 2020. Antioxidant and antimicrobial capacity of Lactifluus rugatus and its antiproliferative activity on A549 cells. Indian Journal of Traditional Knowledge (IJTK), 19(2): 423-427.

Sevindik M, Akgul H, Pehlivan M, Selamoglu Z. 2017. Determination of therapeutic potential of Mentha longifolia ssp. longifolia. Fresen Environ Bull, 26(7): 4757-4763.

Tewari RK, Yadav N, Gupta R, Kumar P. 2021. Oxidative Stress Under Macronutrient Deficiency in Plants. Journal of Soil Science and Plant Nutrition, 1-28.

Tunçel ÖK, Sarısoy G, Bilgici B, Pazvantoglu O, Çetin E, Ünverdi E, Böke Ö. 2015. Oxidative stress in bipolar and schizophrenia patients. Psychiatry research, 228(3): 688-694.

Zazharskyi VV, Davydenko P, Kulishenko O, Borovik IV, Brygadyrenko VV. 2019. Antimicrobial activity of 50 plant extracts. Biosystems Diversity, 27(2):163-169 